\title{
Misuse OF ENDURING POWERS OF ATTORNEY
}

\section{Rachel Kent}

This paper critically evaluates the Law Commission's recommendations as presented in the Commission's report reviewing Part IV of the Protection of Personal Property Rights Act 1988. This legislation defines the scope for enduring powers of attorney (EPAs). The paper advocates that the establishment of a central register for EPAs will be of substantial benefit, as it will provide an effective means of monitoring the use and misuse of EPAs. The paper concentrates on the effects of the current regime on older people, and it interviews six individuals who are actively engaged in work with older people in the Wellington region to identify the main areas of concern surrounding EPAs. The focus of the interviews was developed from the Law Commission's recommendations against the establishment of a central register. The paper identifies some very real concerns with the current law's ability to curb the misuse of EPAs which leave older people open to abuse. It concludes that the Law Commission needs to re-evaluate the issue of misuse of EPAs as its report does not adequately deal with current flaws in the law.

\section{INTRODUCTION}

Part IV of the Protection of Personal Property Rights Act 1988 (PPPR Act) provides the legislation for enduring powers of attorney (EPAs). The Law Commission has recently reviewed and reported on Part IV as concern had been expressed, especially from Age Concern Auckland Incorporated, ${ }^{1}$ about the lack of protection, particularly for those making EPAs (donors). There is a startling absence of safeguards in Part IV for all persons involved in the use of EPAs, including not only the donors, but also the people who are named as the future substitute decision makers for the welfare or property of the donors (attorneys).

Misuse of EPAs comes in many forms. It can range from a welfare attorney not realising their relative is at risk at home and neglecting to arrange care for them (unintentional neglect) through to a property attorney stealing money from the donor (abuse).

* This article is an edited version of a paper submitted in fulfilment of the requirements of the LLB(Hons) degree at Victoria University of Wellington, 2002.

1 New Zealand Law Commission Misuse of Enduring Powers of Attorney (NZLC PP40, Wellington, 2000) 1. 
The Law Commission acknowledged that there was enough concern about misuse of EPAs to warrant investigation. ${ }^{2}$ A preliminary discussion paper was issued in May 2000 and called for interested parties to make submissions. The Law Commission's Report was published in April 2001 and it made a series of recommendations. ${ }^{3}$

This paper will evaluate the Law Commission's recommendations with a particular focus on the issue of registration. The Law Commission was not convinced that a registration system, whereby all EPAs are held at a central register, was going to be of particular benefit. This paper will focus on whether the establishment of a central register should be reconsidered as an effective means to monitor the use and misuse of EPAs. The PPPR Act affects people of all ages, however this paper will concentrate on how this law affects older people and what impact the Law Commission's recommendations will have on this particular group.

In order to identify the main areas of concern and the depth of the problem in Wellington, the author interviewed six people who work with older people in the Wellington region. These were Margaret Sanders, Senior Social Worker for Older People; Alison Holman, Needs Assessor for Older People and ex District Nurse; Shirley Marshall, Psychogeriatric Social Worker; Dr Greg Young, Psychogeriatrician, Hutt Valley Health; Dr Crawford Duncan, Psychogeriatrician, Capital and Coast Health; and Bev Burns, Coordinator for the Elder Abuse and Neglect Service of Age Concern Wellington.

The questions asked of the interviewees covered a range of issues. The questions mainly focused on issues of competency and assessment, whether attorneys should be able to benefit themselves out of the donor's property, the issue of registration and the recommendation that there be a Commissioner for the Aged. These questions were developed from the Law Commission's recommendations. The author also was aware that these were central issues for people involved in care and health services for older people. The author has been a social worker with older people, has a working knowledge of the PPPR Act and has been witness to many instances of misuse of EPAs.

This paper uses quotes directly from the interviewees. In some instances the interviewees have given examples of cases in their work. In order to protect the identities of their clients or associated people, the interviewees' names have not been attributed to those particular quotes.

\section{THE LAW IN CONTEXT}

Although the law was mainly created as a response to the needs of intellectually disabled people, it has now become of major relevance to New Zealand's increasing older population. By the year 2031, it is estimated that 19.5 per cent of New Zealand's population will be over the age of 65

2 New Zealand Law Commission, above, 1.

3 For a summary of the recommendations see, above, 20. 
years. ${ }^{4}$ As our population ages so does the prevalence of dementia. Alzheimers NZ estimates that approximately 38,000 New Zealanders are affected by a form of dementia, the most common of these being Alzheimers Disease. About 8 per cent of people aged over 65 years have a form of dementia. 20 per cent of all clients of the Age Concern and Neglect Service during 1998/2002 had a diagnosed form of dementia. Based on this information, people with a dementia are more likely to be abused. ${ }^{5}$

Statistics on Elder Abuse were not available in New Zealand until $1994 .^{6}$ There were 745 cases of elder abuse nationally in a 12-month period (1 July 2001 - 30 June 2002). ${ }^{7}$ The most common form of abuse was psychological (869 episodes reported), with financial abuse being the next most likely (718 episodes reported). ${ }^{8}$ Sons or daughters were the largest group responsible for the abuse with friends or neighbours being the next most likely group to abuse an older person. Most abusers were related to the older person. ${ }^{9}$ This is disturbing considering the majority of attorneys are thought to be a donor's close family relative. Financial abuse is the fastest growing form of elder abuse. ${ }^{10}$ This is related to "greed leading to opportunistic or well planned exploitation, family expectations around inheritance and cultural differences surrounding the use and management of older people's finances". ${ }^{11}$

It is difficult to know the extent of EPA misuse and abuse. However, Age Concern were aware of at least 46 cases involving abuse from Nov 2000 - June 2001. ${ }^{12}$ Nine out of the 46 were abusing property only, 6 welfare only, but 20 were abusing both property and welfare. The total number of

4 David Richmond and others Care for Older People in New Zealand - A Report to The National Advisory Committee on Core Health and Disability Support Services (Ministry of Health, Wellington, 1995) 20.

5 Age Concern New Zealand Incorporated Report of Age Concern Elder Abuse and Neglect Services - An Analysis of Referrals (for the period 1 July 1998 to 30 June 2001) (Auckland 2002) 10.

6 Age Concern Auckland Incorporated Current and Future Implications for the Older Population with the Enduring Power of Attorney Provision (submission to Law Commission), Auckland, 14.

7 Age Concern New Zealand Incorporated Report of Age Concern Elder Abuse and Neglect Services -An Analysis of Referrals (for the period 1 July 1998 to 30 June 2001) August 2002, 6.

8 Age Concern New Zealand Incorporated, above, 13.

9 Age Concern New Zealand Incorporated, above, 11.

10 Dr Deborah Setterland, Dr Cheryl Tilse and Dr Jill Wilson "Older People's Knowledge and Experiences of Enduring Powers of Attorney: The Potential for Financial Abuse" (Queensland Law Society Incorporated, Brisbane, 2000) $1<$ http://www.qls.com.au/education/eaf/eaf-papers-setterland.htm> (last accessed 4 April 2002).

11 Setterland, Tilse and Wilson, above, 1.

12 Age Concern New Zealand Incorporated Report of Age Concern Elder Abuse and Neglect Services -An Analysis of Referrals (for the period 1 July 1998 to 30 June 2001) (Auckland, 2000) 15. 
EPAs in New Zealand is unknown but the Public Trust in Auckland has executed over 30,000 with less than 2000 being currently active. ${ }^{13}$

Beaulieu and Spencer ${ }^{14}$ have studied the social values that underlie the laws involving older adults and the barriers to justice for older people. They note:

There are three contradictory responses to older adults in the law:

(a) they ignore they exist

(b) treat them as frail, incapable, vulnerable, or in need of special protection;

(c) treat them exactly the same as younger adults, even when there are obvious differences necessitating different treatment under the law (assumed equal ("neutral") application of the laws affecting adults and older adults.)

Legal literature also tends to stress the limitations of older people. Lawyers are constantly warned to question who their client is and are reminded that the client is not necessarily the family member who accompanies the older person. The underlying assumption is that lawyers act inappropriately towards them and, because of prejudice or paternalism, they wrongly assume that a family member's interest will be the same as the older adult's. ${ }^{15}$

\section{THE HISTORY AND THE CURRENT LAW}

Part IV of the PPPR Act (the Act) was inserted in the legislation as an "afterthought"16 at select committee stage. ${ }^{17}$ The Act replaced the Aged and Infirm Persons Protection Act 1912 and Part VII of the Mental Health Act $1969 .{ }^{18}$ The legislation came about mainly in response to pressure from sectors of the community working with intellectually disabled people. ${ }^{19}$ Part IV was seen as a significant piece of legislation allowing for a power of attorney to endure beyond the onset of

13 Sue Martin Enduring Powers of Attorney (submission to Law Commission, 24 July 2000) 2. Clearly not all EPAs are made by older people.

14 Marie Beaulieu and Charmaine Spencer Older Adults' Personal Relationships and the Law in Canada: Legal, Psychosocial and Ethical Aspects, a report commissioned and published by the Law Commission of Canada (1999), Chapter III <http://www.lcc.gc.ca/en/themes/pr/oa/spencer/spencer/html> (last accessed 16 July 2002).

15 Beaulieu and Spencer, above, Chapter III.

16 New Zealand Law Commission Misuse of Enduring Powers of Attorney (NZLC PP40, Wellington, 2000$) 1$.

17 WR Atkin "The Courts, Family Control and Disability - Aspects of New Zealand's Personal and Property Rights Act 1988" (1988) 18 VUWLR, 345, 347.

18 WR Atkin "Enduring Powers of Attorney in New Zealand" [1988] NZLJ, 368.

19 "The Courts, Family Control and Disability", above, 346-347. 
mental incapacity. ${ }^{20}$ Prior to this, a power of attorney was valid so long as the donor retained mental capacity. The relationship between the donor and attorney was essentially a relationship of agency. ${ }^{21}$ This was inadequate, as at the time when the EPA was most often needed, for example, when the older person lost mental capacity due to the progression of dementia, the EPA was rendered invalid. ${ }^{22}$

Under the current legislation a donor may create an EPA as long as it is substantially in the form in the Third Schedule to the PPPR Act. ${ }^{23}$ Both the donor and the attorney must sign it and each signature must be witnessed, ${ }^{24}$ but currently legal advice or a solicitor's presence is not required. For a donor to be able to create an EPA they must have legal 'capacity' or 'competence'. There are no explicit guidelines in the Act as to what this actually constitutes in practical terms. With regards to property, however, some clarity is provided in the case of $R e K^{25}$ A person at the moment of execution must understand the nature and the power conferred but need not have the capacity to transact his or her own business.

A donor can create an EPA in relation to property or care and welfare or both. With regard to property a donor can authorise the attorney to act in relation to the whole or a specified part of the donors affairs. The EPA can be subject to restrictions and conditions. ${ }^{26} \mathrm{~A}$ donor can choose whether the attorney is authorised to act in relation to property either immediately or on the donor becoming partly or wholly mentally incapable. The donor can choose one or more persons or a trustee corporation to manage their property.

With care and welfare a donor can authorise an attorney to act generally or in relation to specific matters. It can also be subject to conditions or restrictions. ${ }^{27}$ The donor can choose only one person to be the welfare attorney and it cannot be a trustee corporation. ${ }^{28}$ The welfare attorney can only act when the donor becomes mentally incapable. ${ }^{29}$ Section 94 provides a definition of mentally incapable. For property, a person is mentally incapable "if the donor is not wholly competent to

20 Protection of Personal Property Rights Act 1988, s 96.

21 "Enduring Powers of Attorney in New Zealand", above.

22 "Enduring Powers of Attorney in New Zealand" above.

23 Protection of Personal Property Rights Act 1988, s 95 (1) (a).

24 Protection of Personal Property Rights Act 1988, s 95 (1) (b).

$25 \operatorname{Re} K$ [1988] 2 WLR 781, followed in Re Tony (1990) 5 NZFLR 609; Re EW (1993) 11 FRNZ 118, 120.

26 Protection of Personal Property Rights Act 1988, s 97 (1).

27 Protection of Personal Property Rights Act 1988, s 98(1).

28 Protection of Personal Property Rights Act 1988, s 98(2).

29 Protection of Personal Property Rights Act 1988, s 98(3). 
manage his or her own affairs in relation to his or her property". ${ }^{30}$ For welfare, a person is mentally incapable if they wholly or partly lack the capacity to understand or foresee consequences of decisions regarding their welfare or cannot communicate their decisions. ${ }^{31}$ At present, the presumption of competence principle in section 5 PPPR Act does not apply to Part IV. However the Law Commission has recommended that this be so. ${ }^{32}$ This is consistent with section 5 PPPR Act. This recommendation is uncontroversial and reinforces a positive view of older people.

The Family Court oversees the PPPR Act and can revoke the appointment if it determines that the attorney has not acted in the donor's best interests. This is a reactive role, as opposed to proactive, as the court will only act if an interested party has made an application.

\section{THE MAIN ISSUES}

The main principles of the PPPR Act include the presumption of competence, least restrictive intervention, the principle of encouragement, best interests, community integration and procedural rights and safeguards. ${ }^{33}$ Part IV, however, seemingly lacks many of these main principles. The only principle which actually applies to Part IV is least restrictive intervention.

It was Parliament's intention to devise a procedure that was informal, accessible, inexpensive and as lawyer-free as possible. ${ }^{34}$ Not all EPAs are misused or abused. There are many attorneys who faithfully perform their duties and bring a sense of order and stability to a situation that would otherwise be chaotic. Unfortunately, however, there are instances of misuse and the law as it stands leaves donors wide open to this. There are no in-built accountability mechanisms. There are no explicit guidelines to assist solicitors to ascertain whether someone has mental capacity to create an EPA. There are also no guidelines regarding when an EPA, particularly in relation to care and welfare, can and should be invoked. There is also no central body to audit and review the creation and use of EPAs. This is extraordinary given that, once this deceptively simple document is invoked, it creates a unique relationship that carries significant and broad powers. These powers cut across the numerous laws covering self-determination. It allows one person to make both minor and major decisions about someone's affairs and care and welfare without any supervision.

The Law Commission ${ }^{35}$ identified five main areas where misuse of EPAs exists:

30 Protection of Personal Property Rights Act 1988, s 94(1)(a).

31 Protection of Personal Property Rights Act 1988, s 94(b).

32 New Zealand Law Commission Misuse of Enduring Powers of Attorney (NZLC R71, Wellington, 2001) 13.

33 WR Atkin "The Courts, Family Control and Disability - Aspects of New Zealand's Personal and Property Rights Act 1988" (1988) 18 VUWLR, 345, 349-351.

34 Misuse of Enduring Powers of Attorney, above, 3.

35 Misuse of Enduring Powers of Attorney, above, 8. 
- Abuses in relation to the initial granting of the EPA, for example undue influence by attorneys or where a donor lacks capacity;

- Neglect of the donor by the attorney, for example failure to institutionalise the donor because of the resulting loss of inheritance;

- Embezzlement of moneys and theft of property;

- High-handedness, failure to consult and bullying of the donor; and

- Problems with the 'mentally incapable' test in section 98(3), which must be satisfied before a welfare attorney can act.

Any reform aimed at curbing abuse of this quiet document must be mindful of retaining its usefulness. Abuse will occur even where the laws are extremely invasive, ${ }^{36}$ so ideally any statutory modification must achieve some sort of balance. The Law Commission was committed to retaining 'the great virtues of Part IV procedures' - the cheapness and power of the donor to decide who should be the attorney. ${ }^{37}$ The Law Commission has made some recommendations. However, as will be shown, these do not go far enough to protect the parties involved, in particular the donor.

\section{A The Law Commission's Main Recommendations}

If the attorney is a person other than the donor's spouse or de facto partner and if the donor at the time of executing is either aged 68 years or over or a resident in any hospital home or other institution, valid execution would, following the Law Commission's recommendation, require compliance with the following:

- A solicitor must witness the donor's signature

- That solicitor must be retained independently by the donor and the solicitor must give the donor advice regarding:

(1) matters referred to in the Third Schedule which include whether the donor wants the EPA to continue passed mental incapacity, if and how they want an attorney to benefit themselves or others;

(2) the donor's choice of attorney(s), for example two for property and one for welfare;

(3) that the donor has a choice over whether the attorney can act in relation to property or welfare or both;

36 Karen E Boxx "The Durable Power of Attorney's Place in the Family of Fiduciary Relationships" (2001) 36 GALR $1, \quad 18<$ <ttp://international.westlaw.com.result/text.wl?RecreatePath=/Welcome/Westlaw International $>$ (last accessed 14 June 2002).

37 Misuse of Enduring Powers of Attorney, above, 16. 
(4) that conditions can be imposed (for example "not to sell the family home");

(5) if and how they want an attorney to be monitored; and

(6) that the donor can revoke the EPA at any time, if the donor has capacity.

Other recommendations include:

- $\quad$ There should be a "presumption of competence" principle incorporated;

- A registered medical practitioner needs to state in writing that the donor is mentally incapable before an attorney can act in relation to personal care and welfare;

- $\quad$ The donor must be wholly mentally incapable (as opposed to 'partly');

- An attorney is obliged to encourage the donor to participate in the decisions about their property and their personal care and welfare as much as possible AND consult the donor or other interested parties for advice regarding any decisions;

- A breach by the attorney of the above obligations should be a ground for revocation. A social worker, doctor, representative of a voluntary organisation or any other person (with leave of the Court) should be able to apply for revocation;

- That consideration is given to the creation of the position of the Commissioner for the Aged, to act as a champion for older people.

\section{B What The Law Commission Rejected}

- A central registration system holding all EPAs. It was acknowledged it would be easier for professionals and institutions to find out if an EPA existed and would prevent multiple EPAs from being made, but the Law Commission believed the benefits did not outweigh the resultant expense and loss of privacy. ${ }^{38}$

- A certificate of capacity by a medical practitioner before an EPA could be created. The Commission saw that solicitors regularly make similar judgements regarding capacity in relation to the execution of wills and consult medical practitioners if in doubt.

- That specialists should do the competency assessments, not medical practitioners, before the EPA can be invoked. The belief was that this role should stay with medical practitioners and, if there was any doubt, the medical practitioner should obtain a specialist opinion.

38 Misuse of Enduring Powers of Attorney, above, 18. 


\section{WHAT THE LAW COMMISSION SHOULD RECONSIDER}

\section{A The Criteria for When a Solicitor is Required}

In order to retain the informal nature of Part IV, the Law Commission wanted to limit the circumstances in which a solicitor was required. It recommended it be limited to situations where:

(a) the donor is over 68 years;

(b) the attorney is not the donor's spouse or partner; and

(c) when the donor is in an institution.

Although the Law Commission acknowledged that "whatever age we propose is likely to attract taunts that we are purporting to impose an age of statutory senility," ${ }^{139} 68$ years was deemed an appropriate age. This is fairly arbitrary and it unfortunately ignores situations where people suffer an early onset of dementia or others under 68 years who need protection. Furthermore, this is ageist and the Law Commission almost acknowledges this in the above statement.

Although an older person is more likely to be abused by their son, daughter or another relative, spousal abuse does occur. ${ }^{40}$ There is a multitude of cases involving spouses and undue influence and the law has been particularly protective of wives. ${ }^{41}$ As Dr Crawford Duncan asserts:

Anyone is capable of being unduly influenced ... there is no logic as why you should try and protect that group of people and not other groups of people ... if undue influence is the issue.

The recommendation that legal advice is necessary when the donor is in an institution is also an ageist assumption. There is no reason why older people living in the community require less protection than those in residential care. With the heavier emphasis and use of community home support, the dependency levels of people now entering residential facilities is increasing. ${ }^{42}$ But many residents still retain all of their mental faculties. There are some people living in the community who are less mentally alert than people in residential care.

Legal advice is not needed to make a will. The difference with an EPA, however, is that because it comes into effect while the donor is still alive, it inevitably has more of an impact on the donor. The creation of the EPA is therefore very important. Having artificial criteria for this will not work

39 Misuse of Enduring Powers of Attorney, above, 10.

40 Age Concern Auckland Incorporated Current and Future Implications for the Older Population with the Enduring Power of Attorney Provision, (submission to the New Zealand Law Commission) (Auckland 2000) 72 (Appendix 1 C I )

41 See Royal Bank of Scotland v Etridge [2001] 3 WLR 1021 (HL).

42 David Richmond and others Care for Older People in New Zealand - A Report to The National Advisory Committee on Core Health and Disability Support Services (Ministry of Health, Wellington, 1995) 56. 
well enough, as there will be groups of people who will not be protected. Given the significance and ramifications of this decision, legal advice should be mandatory.

\section{B Wholly Lacking Capacity?}

The Law Commission recommended that section 94(b) be amended to be more in line with section 12(2) of the PPPR Act. There are some problems with this recommendation. Some of the interviewees believed that if the definition of 'mentally incapable' was narrowed to include only those people wholly lacking capacity, the attorneys for a large number of partially competent people at real risk would not be able to act.

... people have to be extremely incompetent to be assessed as wholly lacking capacity and people who are partially incompetent can still be taken advantage of and need representation. (Margaret Sanders)

The definition of 'wholly' is not clear. The concept of competence is a key concept in the field of older people's rights and no other social group is so directly influenced by its definition. ${ }^{43}$ As $\mathrm{Dr}$ Greg Young, psychogeriatrician asserts:

It depends how you define wholly ... if it's ... literal, that is an extreme situation.

Dr Crawford Duncan takes the following view:

of course the problem ... is that we are all relative and there is no "wholly" loss unless you are dead or unconscious ... absolutes don't exist in real life so the problem is how you define wholly.

If a psychogeriatrician is not sure what 'wholly' lacking capacity is, how will general medical practitioners be able to interpret this concept? There was concern that this would actually exclude a lot of people and they would not get their needs met. All but one interviewee were very clear that many people who were partially competent actually needed help from their attorneys on occasions with decision-making.

... competency is not an all or nothing phenomenon and it is difficult to know what the meaning of "wholly lacking competence" is. It's quite possible a person may lack competence in one area and retain competence in another area and therefore it's appropriate for them to make a decision, but there may be (other) decisions ... which are ... not in their best interests and they may not realise that. (Dr Greg Young)

The example that was most used was that of someone with frontal lobe dementia.

[People with] frontal lobe dementia ... may make perfectly reasonable decisions about their property, but very bad decisions about their welfare because they fail to see they have any medical problems at

43 Israel Doron "From Lunacy to Incapacity and Beyond - Guardianship of the Elderly and the Ontario Experience in Defining Legal Incompetence" (1999) 19 Health L Canada 95, $100<\mathrm{http} / / /$ www.lexis.com/> (last accessed 14 June 2002). 
all...their property is managed according to long ingrained habits ... On the other hand their health may be changing because they are old ... but they are unable to modify their behaviour ... according to their new health circumstances. (Dr Greg Young)

At present section 94 is very broad and does not provide any clear direction as to what constitutes partial capacity. There is enormous variation within the concept, ${ }^{44}$ for example 5 per cent capacity - 50 per cent capacity, and questions arise as to how incapacitated someone has to be. But narrowing this definition to include only those who have wholly lost capacity does not solve the problem but creates a whole new set of difficulties.

If we discharged everybody home, with frontal lobe dementia, who said they wanted to go home we

would send home a large number of people who were at extreme risk. (Margaret Sanders)

In contrast, Shirley Marshall did not have too much difficulty with this increased threshold. Although she acknowledged that it is time consuming working with people with partial capacity, she believed that this was acceptable.

Any reform of section 94 should keep the partially incompetent component. At the same time the definition should be carefully written to provide a more precise explanation of what 'mentally incapable' actually means. Those writing the definition should be the clinicians that have the greatest knowledge in this area. There should also be guidelines written to assist medical practitioners and specialists in the application of the mentally incapable test.

\section{Encouragement}

It is suggested that an attorney should encourage a donor to participate as much as possible in decision-making, both in relation to personal care and welfare and property. This allows for consistency with section 18(3) and (4). ${ }^{45}$ This recommendation is relevant for a donor who is still interested in their financial affairs but does not want to manage them.

... certainly with property, even though you've given away that power because you choose to, you still

have a right to be informed about what's going on and that doesn't always happen. (Bev Burns)

In relation to care and welfare, however, this recommendation is irrelevant. If the donor needs to be wholly (as opposed to partly) mentally incapable before an EPA can be invoked, it is highly unlikely they will understand any suggestion, option or consequence of any decision which needs making.

44 Age Concern Auckland Incorporated Current and Future Implications for the Older Population with the Enduring Power of Attorney Provision, (submission to Law Commission), Auckland, 31.

45 New Zealand Law Commission Misuse of Enduring Powers of Attorney (NZLC R71, Wellington, 2001) 21. 


\section{Solicitors to Make Sure Donors Have Capacity}

Before a donor creates an EPA, any solicitor involved needs to be sure that the donor is legally competent. If the Law Commission's recommendations are implemented regarding when a solicitor needs to be involved, then there will be an increased use of solicitors in the process. The Law Commission conceded that there was wide concern from health professionals about the ability of lawyers assessing mental capacity. ${ }^{46}$ However, they believed that this role should stay with lawyers, as it was something they did regularly anyway, particularly in relation to the execution of wills. The Law Commission believed that "of course they will be financially liable if any negligent breach of their professional obligations in this respect is causative of loss". 47

The case of Re EW is a classic example of when a lawyer assisted someone to make an EPA when the donor was clearly incompetent. In that case, an EPA was found to be invalid after a woman with advanced Alzheimers Disease, who was a resident in a secure unit, signed an EPA. A lawyer, at the request of the woman's son, visited her with the prepared EPA. He was with her for 15 minutes and thought that "she was fully competent and aware of what she was doing and had full capacity in dealing with her affairs at that time". ${ }^{48}$ Any general knowledge of the type of resident in a secure unit would alert you to question whether this person has competence.

It is unethical for a lawyer to allow an incompetent client to execute an EPA. ${ }^{49}$ Besides the common law rule that a client must be able to understand the nature and extent of the power conferred but not necessarily be capable of managing all of their affairs, ${ }^{50}$ there are no guidelines for solicitors to follow. Worse still there is no specific way of monitoring the accuracy of their judgements.

There are times I am aware of where a person has signed an EPOA one-day and it's acted upon the next.

That seems quite miraculous that somebody's competence has changed overnight. (Shirley Marshall)

All interviewees had concerns about this area of the law.

A lawyer would need a lot of training. I don't see why a lawyer should have that role of determining

mental capacity. (Alison Holman)

46 Misuse of Enduring Powers of Attorney, above, 12.

47 Misuse of Enduring Powers of Attorney, above, 12.

$48 \operatorname{Re} E W(1993) 11$ FRNZ 118, 123.

49 See John M Hall "The Ethical Duty to Assure a Client's Competency When Preparing Powers of Attorney" (Feb 1992) Vermont Bar Journal and Law Digest $34<$ http://www.international.wetlaw.com> (last accessed 14 June 2002).

$50 \operatorname{Re} E W$, above, 123. 
Although most thought that requiring a medical certificate of competency would be too onerous, they all believed the guidelines, training and monitoring around this process needed to be better.

I talk to quite a few lawyers about this and they usually know, like doctors, that you have to be able to express a view, and they tend to regard consistency as being tantamount to competency. But of course they are not the same thing. If you doggedly say one thing it doesn't mean it's a competent view ... so I don't know that lawyers do this well by and large ... some obviously have a very good idea so I wouldn't

like to suggest they couldn't do it (Dr Greg Young)

Most of the interviewees could cite recent situations where a solicitor had assisted a donor to make an EPA when the person was not competent and three of the interviewees had had experience of this in the last few months. One interviewee had had a situation where a lawyer, from a leading Wellington law firm, went to a woman in a public hospital and, other than the fact that the woman was quite delirious with an acute illness, she had known dementia. The lawyer felt that it was all right to have her sign the EPA.

He'd actually had the papers for some length of time for her to sign for welfare and property, but deemed it the appropriate time to have them signed while she was in the ward, acutely unwell. He felt that it was still OK.

If the lawyer had read the medical notes, it would have been obvious that the woman was not competent. She died not long after that.

There was another instance where a neighbour of a patient had asked a lawyer to create an EPA with the patient, making the neighbour the attorney for welfare and the neighbour's partner the attorney for property. They intended to buy the patient's house once the EPA had been invoked. The health professional involved had specifically told them not to proceed with any major legal action. However the lawyer and the neighbour came to the ward in the hospital and had the forms signed anyway. The patient had frontal lobe dementia, so he could not spontaneously generate any new ideas for himself. I asked the involved health professional if it would have been obvious to the lawyer that the patient was incompetent:

I don't think he would have come across as particularly good. If you talked to him for more than 5 minutes you would have realised he was telling you the same stories. He was a man who had read widely and so he will sound better than he [really is] because he talks off the point, gives you lots of spurious information ... He didn't foresee that if he sold the house to his neighbour, the neighbour would then own the house and he would have to pay [the neighbour] rent.

Without any kind of regulation or standardisation, we do not know how often this kind of situation occurs. What is clear, however, is that lawyers need some training in this area. Lawyers need to know what questions to ask people, for instance what the donor sees their options to be in the situation and what consequences they anticipate from their actions. 
In Dr Crawford Duncan's experience, lawyers will only seek a second opinion for their client if the person appears to be seriously mentally impaired. He believes that in most instances this is acceptable, particularly if the situation in not contentious. In his opinion, lawyers need to be aware of situations where there is contention and investigate further. He holds the view that the law needs to retain the principle of least restriction and that people should have the opportunity to sort out their affairs if they can. He agrees, however, that lawyers need some training in this area and how to recognise certain diagnoses.

\section{How can this be better managed?}

There were some suggestions as to how this might be better managed and monitored. Some interviewees came up with the idea that there should be some basic standard screening tool that lawyers could use to determine whether or not a person needed further assessment by a medical practitioner. This could be a mandatory test that lawyers must complete before any EPA is created. The screening tool could be developed by a specific working party that included on it relevant health professionals and interested lawyers. There would need to be some training as to how to use the tool, for example, what indicators to look for, how to ask the questions, making sure that family members do not answer for them etc. This test could be a signed document from the lawyer that could be registered along with other basic information. This would achieve some degree of national consistency and would not only be a safeguard for donors and attorneys, but also for lawyers.

... it would prevent lawyers from being sued... if somebody failed one of those questions. [They could

be referred] ... to the GP ... it could be a really formalised process. (Margaret Sanders)

The relationship of trust and confidence between a lawyer and client would be protected if this were a nationally mandated process. If the donor fails a question on the initial screening test, the lawyer could reassure the donor that it is not the lawyer making assumptions or value judgements about the client's competency, but rather a procedure has to be followed. This would hopefully prevent the client from getting angry with the lawyer.

The Law Commission's statement about the option to sue lawyers if they are negligent in assessing a donor's capacity is out of touch. It is highly unlikely that there will be much litigation in this area.

If a lawyer is OK about doing this [preparing an EPA] when a person is knowingly obviously

incompetent, there can't be a lot of risk of being sued. If a lawyer with a renowned company in our city

is quite happy to do that he didn't obviously think there was much of a risk in doing it. (Anonymous)

There is little, if any, case law in this area and, as the Law Commission states, people have always had the option of suing lawyers in negligence. New Zealand is not a highly litigious society, so this suggestion is not useful. 


\section{E Medical Practitioner's Testing for Competence}

Although there is some doubt about whether all medical practitioners have the skill to undertake competency assessments, the Law Commission rejected the proposal that competency assessments need to be done by specialists. They believed that this would be impractical, as there are not enough specialists to cater for the need. Those in rural areas would be particularly disadvantaged. However three of the interviewees thought that a person should, ideally, have some input from a specialist. Bev Burns acknowledged that although travel would be an issue for people, she thought it was necessary to have some specialist input.

... older people are so convincing. The GP can ask if the person 'Have you cooked a meal? Have you done some shopping? And the older person says yes, yes, yes and they haven't ... Some GPs ... just don't understand the special needs of older people ... I'd hate it to be taken away from some GPs, but I'd err on the safer side. It should be from the Geriatrician. (Bev Burns)

In contrast Dr Greg Young thought that medical practitioners, and in addition psychologists, could hold this role.

Doctors are in fact engaged in competency assessments all the time because every time they ask a patient to consent to treatment, there's an implied assessment of the competency of the patient ... so [doctors] have to know how to do this ... Many doctors are not comfortable with doing that assessment and that's consistent with many believing it is a psychiatric role ... I think it's very easy to train doctors to do it at a basic level. (Dr Greg Young)

Shirley Marshall believed that, as long as the GP has a good relationship with their patient, then they would be in a position to determine competency.

I think any extra training around competency would be quite valuable because even people in a hospital environment don't understand competency, it's hugely complex. (Shirley Marshall)

There needs to be a recommendation that medical practitioners who undertake these assessments have to have had some formal training in this area. The requirement that a medical practitioner certifies in writing that a donor has become mentally incapable is the minimum one would need to make this process safer for donors. The certificate stating that someone is incompetent should also be registered at a central register.

\section{F The Third Schedule}

The Third Schedule to the PPPR Act sets out the requirements for the EPA document itself. In its current form, the document is very simple and does not require much detail. It does not prompt a donor to consider many options. The Law Commission made no suggestion that the Third Schedule be altered, but instead recommended that a solicitor should advise donors of all the options available to them when creating an EPA. This may work for those who use a solicitor. If the Law Commission's recommendations are implemented regarding the use of a lawyer, there will be people 
still making EPAs without legal input. The Third Schedule in its current form is of little use to those people.

It's too loose; there's nothing in there telling anyone what it's about (Alison Holman)

Again the Law Commission suggested that in the cases where a solicitor is used and they fail in the task of advising clients of all options, they could be sued for negligence. As noted before, this suggestion seems out of touch. If it is the older person who is the victim of a solicitor's negligence, they are even less likely to sue. ${ }^{51}$

If solicitors fail to inform donors of their options, donors may never actually find out what their options are. The Third Schedule notes are brief and do not cover every possible option. The Law Commission recommended that solicitors advise donors that the EPA can be revoked. But there is nothing in the document itself to remind people of this. It is unlikely that a donor will vividly remember legal advice given to them, in some cases, many years ago. It is easily remedied by making the Third Schedule a much fuller, less legalistic document, which both prompts people to consider their options when creating an EPA, and then reminds them of what their options are if they were to later re-look at the document.

There are more options to be considered than just the ones that are mentioned. Age Concern suggests donors give a copy of the EPA to their bank if the attorney is going to have to operate their bank account. The Third Schedule could also alert people to think about more minor, but meaningful things. For example:

I think people are thinking about the major things, but they're not thinking about those little day to day things ... like this lady who has had her hair set every week ... and you know that if it didn't continue after she had lost [capacity], she would be horrified. (Bev Burns)

And Alison Holman would like to see more prompts in the document regarding competency testing:

There is nothing in there, which prompts people to think about who they want determining their competency. (Alison Holman)

Bev Burns also suggested that lawyers should be responsible for ensuring EPAs are reviewed and the Third Schedule could invite a donor to think about whether they wanted to review the EPA and when they would like to do this. The EPA could also prompt donors to decide whether they wanted their property manager to supply regular reports so they can be informed about their on-going financial situation. Handing in financial reports is not only a safeguard for donors, but also for attorneys as their dealings are then transparent.

51 See Marie Beaulieu and Charmaine Spencer Older Adults' Personal Relationships and the Law in Canada: Legal, Psychosocial and Ethical Aspects, a report commissioned and published by the Law Commission of Canada (1999), Chapter III <http://www.lcc.gc.ca/en/themes/pr/oa/spencer/spencer/html $>$ (last accessed 16 July 2002). 
Attorneys also need to be given much more information and told what their responsibilities entail. To emphasise the importance of the role of the attorney, explanatory notes to the EPA could include the fact that their decisions as attorney could be subject to review by the Family Court. The document could also contain fuller advice on where to go to get information or assistance. Crekye suggests that the importance of the document could be emphasised by the use of stiff paper or even a state seal. ${ }^{52}$ These are small alterations to the law but could have powerful effects giving donors more control over their future and enabling them to be fully aware and informed of what they are signing.

\section{G Monitoring of Attorneys}

The Law Commission recommends that solicitors should discuss with donors whether they want anyone monitoring the attorneys. This assumes that people will foresee a risk of some kind, which is hard to see if you are the mother making a daughter or son your attorney.

I think people would be reluctant to choose somebody they ostensibly trust to be an EPA and then appoint somebody else to monitor them. There is a slight suggestion that maybe you didn't trust them. (Margaret Sanders)

It is often complicated for people to understand what an EPA entails and making this more complicated may put them off making one.

\section{H A Registration System?}

The Law Commission acknowledged that a registration system would make it easier for professionals and institutions to find out if there was an EPA in existence and also prevent multiple EPAs from being made. However, this was clearly not reason enough to recommend a registration system. Perhaps the amount of time that health professionals and others spend on finding out this information was not fully appreciated.

It's a monumental time waster. (Dr Crawford Duncan)

All interviewees stated it would be very useful and time saving to be able to contact a central register to check and see if someone had an EPA.

For myself and my colleagues who have been dealing with some situations where there have been dual EPOA, a register would be great. (Bev Burns)

If there is a central register, everyone will know where a copy of the EPA document actually is. It is unlikely that someone living alone with worsening dementia has important documents in easy to find places. The EPA would be a lot safer if held by a central register. Although Bev Burns was

52 Robyn Creyke "Privatising Guardianship - The EPA Alternative" (1993) 15 Adel LR 79, 90. 
concerned about the accuracy of a registration system, she agreed that the development of some kind of central register was very important, as did all of the other interviewees.

It's the way to go, I feel quite strongly about that. (Alison Holman)

Dr Crawford Duncan believed registration of EPAs was also very important.

[w]e ... accept that when you're born you're registered and that when someone dies you register it and ... marriages ... we register houses, we register cars. These are documents that are really important. (Dr Crawford Duncan)

And in the case of the man with frontal lobe dementia discussed previously:

... The neighbour subsequently claimed the patient had previously signed over EPA to him but could never produce the documents ... if [EPAs] were registered, it's all there.

Although the Law Commission acknowledged that a registration system would be useful to institutions and professionals, it believed the benefits did not outweigh the resultant expense and loss of privacy. ${ }^{53}$ The Queensland Law Reform Commission possibly influenced it. Its review came down against registration because of cost, invasion of privacy, delay, bureaucracy, and inability to detect or deter fraud.

\section{Privacy?}

None of the interviewees thought that this was a hugely important issue. Most actually believed that given the powers an attorney holds, it is important that their actions are transparent and subject to scrutiny.

I can't see that it's of any consequence that people do know [that an EPA exists] ... I don't see how it could damage a client; it could only protect them and the decisions they made when they were competent (Alison Holman)

The choosing of an attorney is sometimes a sensitive area, particularly in families where there might be conflict. However as Margaret Sanders asserts:

Just because you've personally chosen them, it doesn't mean that they shouldn't have some public accountability ... I don't think it's a big deal.

The interviewees believed there should be some restrictions on who has access to the register and anyone requesting information from the register should have a justifiable and demonstrable interest. Shirley Marshall thought it might work if the EPA document prompted donors to make decisions regarding who had access to the information.

53 New Zealand Law Commission Misuse of Enduring Powers of Attorney (NZLC R71, Wellington, 2001) 18. 
I don't think that this would just be for public viewing. (Dr Greg Young)

The cost of privacy must be balanced against the risk of misuse and abuse. Any legislation which provides good protection must allow for some infringement on basic privacy rights. As Dr Greg Young stated:

I don't believe that by and large that that would be a practical issue ... it depends on just how paranoid you want to be about that. (Dr Greg Young)

\section{Too expensive?}

The Law Commission thought a registration system would be too expensive. It was unclear as to whether this was referring to the setting up of the system itself or whether it would be too expensive for donors. However if a system was set up, one could assume that some of the cost would inevitably be passed on to consumers. Most of the interviewees were sceptical about the Law Commission's reasoning.

Too expensive? What's too expensive? Having people protected? (Alison Holman)

Both Margaret Sanders and Greg Young thought it was important to consider how costly it was not to have a registration system. Margaret Sanders emphasised the time involved in cases where there are difficulties surrounding an EPA, for example, finding out whether one exists, or dealing with cases when an attorney has misused an EPA.

I think its probably quite expensive not to have it ... I think the expense that currently exists when an

EPOA [is misused] ... that expense is currently hidden. I would imagine that a lot of that expense is borne by the health sector and private individuals ... doctors and social workers can be involved for months, and there's no reason as to why we should carry that cost if it's preventable. (Margaret Sanders)

Dr Greg Young was concerned about the costs of keeping a person in hospital while a PPPR application is made, and sometimes for no good reason as an existing EPA is found at a later date.

Too expensive is a matter of judgement and it's too expensive for what? (Dr Greg Young)

Saving money may not be possible but a better system may afford people better protection. If finding out whether someone has an EPA or not is, in the words of Dr Crawford Duncan, "a monumental waste of time", then perhaps further research into the actual costs nationwide would be useful. 


\section{Too Bureaucratic?}

Bureaucracy and delays have plagued the registration system in England. ${ }^{54}$ However when asked to comment on whether an increase in bureaucracy was a justifiable reason for not having registration, Dr Greg Young stated:

I think that the Mental Health Act is very bureaucratic but you can't say it is not a worthwhile thing. I

don't think that's acceptable.

Bev Burns was more cautious about the system itself. She was concerned about who might monitor the system and also how accurate the system might be.

No system is fail safe. New Zealand does not have to follow the English example but could instead adopt the parts of their system that are useful. With the advent of computer technology, it would be a relatively straightforward process to set up and maintain an accurate electronic registration database for EPAs. ${ }^{55}$

\section{What Should be on the Register?}

It has been suggested that a national screening test or tool be developed for lawyers to use to do an initial assessment of a donor's competency, prior to the creation of an EPA. In order to achieve national consistency, this assessment should be registered. This would confirm the validity of the EPA and provide protection from litigation for lawyers. The medical certificate stating that a donor has lost capacity could also be registered. Because of privacy issues, only the minimum information would need to be held, and again access to the information should be restricted.

Margaret Sanders was unsure whether information regarding a person's competency, should be on a public register. She suggested that those people who would want to know this information would already be sufficiently involved with that person so as to be aware of the identity of that person's doctor. They would therefore be able to contact that doctor directly. She also thought that it would be difficult to keep this information on competency up to date.

The fact is that there could be a certificate from last year saying that somebody is partially incompetent,

but they are a lot worse now. (Margaret Sanders)

In contrast, Dr Greg Young thought the registering of this information was necessary.

54 Age Concern Auckland Incorporated Current and Future Implications for the Older Population with the Enduring Power of Attorney Provision, (submission to Law Commission) (Auckland 2000) 54 citing two major consultation papers; "Enduring Powers of Attorney" Report to the Lord Chancellor, University of Bristol 1991 and the English Law Commission's report on "Mental Incapacity" (1 March 1995).

55 Misuse of Enduring Powers of Attorney, above, 3. 
You have to explain why this is occurring. It's not normal for a person to lose competence so something has happened to make that person lose competence. I think that's got to be in the register. (Dr Greg Young)

The only other information which would need to be placed on such a database would be the names of the donor and attorney, date of registration, the identity of the lawyer who validated the EPA, the type of power granted and any other specific requests.

\section{J Other Uses for a Registration System}

Dr Greg Young thought that a registration system could be well utilised by staff at Accident and Emergency departments, especially in resuscitation or life support cases.

It would think it could save a lot of $\mathrm{A}$ and $\mathrm{E}$ time and it guarantees better care for that person because you have the appropriate person making decisions for that person. (Dr Greg Young)

The police could use the register to find out whom they should contact if somebody is wandering or causing concern to others. It would also enable hospitals, rest homes and other institutions such as banks to double-check as to whether the EPA was legitimate.

It was also seen as a useful tool in monitoring any attorneys who had created suspicion as to whether they were acting in the best interests of a donor. A registration system could be used to check to see if that attorney was actually acting for any other people at the same time.

\section{K Attorneys Being Able to Benefit Themselves}

The Law Commission suggested that a limit should be imposed on section 107 which provides that attorneys can benefit themselves but only to the extent that donors might be expected to provide for attorneys' needs. This is currently completely unregulated. It was recommended that only a trust corporation could benefit or where there are "joint attorneys who are not spouses and not more than one of them benefits". ${ }^{56}$ But as Margaret Sanders pointed out:

A lot of people could collude together if they wanted to.

Most of the interviewees were well aware that many attorneys work very hard to assist a donor. There is a question of how cost and benefit are defined. While all interviewees thought that attorneys should be reimbursed costs, it was suggested that there should be set statutory limits.

The register was seen as a useful way of auditing how attorneys benefit themselves. Once an EPA is activated, property attorneys should be subject to the same reporting obligations that presently apply to property managers outlined in earlier sections of the PPPR Act. ${ }^{57}$ The financial

56 Misuse of Enduring Powers of Attorney, above, 17.

57 Alan Gluestein Preliminary Paper 40 - Misuse of Enduring Powers of Attorney (submission to Law Commission, 2000) 12. 
reports could be submitted to the registration system just as the reports for property managers are submitted to the courts. ${ }^{58}$ This would hold attorneys to account.

\section{A Commissioner for the Aged}

Most of the interviewees were enthusiastic about the idea of having a Commissioner for the Aged. Many agreed that older people needed stronger advocacy by one central, consistent and more powerful body.

A Commissioner for the Aged is essential ... Elderly who are abused don't live a long time and they don't fuss a lot and they don't have a powerful lobbying group, it is easy to ignore them and that's what happens. (Dr Greg Young)

Some interviewees were not comfortable with the name and preferred Commissioner for Older People.

Older people is a nicer term ... it allows more diversity. The Aged has a very negative image associated with it, that most older people don't subscribe to. (Margaret Sanders)

Margaret Sanders was a little reluctant about having a Commissioner as she thought that there was probably enough representation for older people in New Zealand.

At the moment we've got Grey Power, we've got Age Concern, we've got the Senior Citizens Unit and the Social Policy Agency, and we've got a Minister for Senior Citizens. (Margaret Sanders)

As to what a Commissioner for the Aged could do, it was suggested they could take on the investigative role similar to the Health and Disability Commissioner when there were alleged abuses of older people and misuse of EPAs. A Commissioner could ensure that all policies regarding older people, such as the Positive Aging Strategy, are actually implemented. ${ }^{59}$

Four of the six interviewees emphasised the pressing need for a pool of volunteers to take on the role of welfare guardian for those people who have nobody to perform this role. Although Age Concern is currently in the process of setting up training for volunteers, it was suggested that this could be an appropriate role for a Commissioner.

... inappropriate people are appointed as EPAs and welfare guardians sometimes because there is no one else, so what we need more than anything else is a central group of civic minded individuals who are prepared to be ... welfare guardians (Margaret Sanders)

Lastly, a Commissioner for the Aged could oversee governmental functions and legislation to ensure ageism is not promulgated.

58 Protection of Personal Property Rights Act 1988, s 45.

59 Interview with Alison Holman, Needs Assessor for Older People (the author, Wellington). 


\section{OTHER WAYS TO PREVENT MISUSE OF EPAS}

\section{A Education}

Educating anyone who could be potentially involved in the EPA process has obvious benefits. Age Concern has recently carried out education on EPAs in rest homes and other institutions such as WINZ, however there is still a major problem.

Often we come up with people who have made an EPOA for property but have not made one for welfare issues. (Shirley Marshall)

This creates real difficulties when someone loses capacity as the attorney can, for example, pay for a donor's care in a rest home, but cannot move them there.

The legislation acknowledges the importance of the welfare attorney by granting them rights over the property attorney if there is any conflict. ${ }^{60}$ Unfortunately the legal profession and the public have not yet grasped the importance of having a welfare attorney.

\section{B Tribunals}

Terry Carney, from Australia, suggests that tribunals are a better way to monitor EPAs, as they are more informal, less costly and more accessible than the Family Court. ${ }^{61}$ It has been argued that tribunals actually have their own bureaucratic tendencies. ${ }^{62}$ Certainly a less formal environment where issues to do with EPAs could be dealt with is supported.

... often things come down to a misunderstanding rather than a deliberate abuse. (Shirley Marshall)

If there is a registration system and a Commissioner for the Aged, tribunals may not be required.

\section{Two Attorneys for Welfare}

Alison Holman raised another interesting point as to why the law only allows for one welfare attorney, whereas a donor can choose two attorneys for property.

There will be always differing opinions in families and these need to be resolved anyway ... Why should this be limited to one? If this is because of the potential for conflict, why is there not potential with the property managers? There should be two for welfare and let that be it. (Alison Holman)

60 Protection of Personal Property Rights Act 1988, s 99(2).

61 Terry Carney "Abuse of Enduring Powers of Attorney - Lessons From the Australian Tribunal Experiment" (1991) 18 NZULR 481, 484.

62 John McMillan, Psycho-geriatric Social Worker, Waitemata Health, Auckland (submission to Law Commission, 2000) 4. 
This appears to have been overlooked by the Law Commission, perhaps because it was not seen as a major issue. However the option of having two attorneys for welfare could provide donors with more protection.

\section{CONCLUSION}

The Law Commission has made some recommendations for amending Part IV of the PPPR Act, which provides the procedure under which an EPA can be created and invoked. Although the extent of the misuse of EPAs is not known, it acknowledged that this was a problem facing mainly older New Zealanders. The Law Commission engaged in a balancing act between upholding the "great virtues of the Part IV procedures" and having a regime that affords more protection to donors. Although many of the recommendations are useful, unfortunately the scales come down on the side of the least restrictive intervention, which will leave older people vulnerable to abuse.

All of the people interviewed during this research were able to provide examples where, in their work, they have encountered misuse of EPAs. This paper has used some of these examples to highlight the need for urgent legislative change. The interviewees also made some suggestions as to how the procedures governing EPAs might be altered to enable better use of EPAs and how these might be monitored and reviewed. Five of the six interviewees were adamant that a registration system should be set up. The sixth person believed that there needed to be better monitoring and review of EPAs but was concerned about the bureaucratic accuracy of a registration system. All of the interviewees acknowledged that the law as it stands is unregulated and older people, who need others to make decisions about their welfare and property, deserve better protection.

The Law Commission needs to re-evaluate the issue of misuse of EPAs. Its report does not adequately deal with the current flaws in the law and this will continue to leave older people wide open to abuse. 